\section{Financing Higher Education in Asia: Patterns, Trends, and Policies}

\section{Mark Bray}

Mark Bray is director of the Comparative Education Research Centre at the University of Hong Kong. Address: Pokfulam Road, Hong Kong, China. E-mail: <mbray@hku.hk>.

$\mathrm{T}$ he Asian Development Bank (ADB) is preparing a new policy framework for its work in education. To provide background information for policy formulation, the $\mathrm{ADB}$ commissioned a series of thematic and country papers on trends and issues in the education sector. Higher education is among the domains that has received attention. This article highlights some features from the ADB paper on education financing in the region. ${ }^{1}$

\section{Diversity and Commonality}

The ADB has 37 developing member countries, which display considerable diversity. Populations range from just 7,000 in Nauru to 1,200,000,000 in China. GNP per capita ranges from U.S.\$200 in Nepal to U.S.\$22,500 in Singapore. Moreover, the group includes states that remain officially committed to a socialist ideology (People's Republic of China, Lao People's Democratic Republic, and Socialist Republic of Vietnam), while others (e.g., Kyrgyz Republic, Cambodia, Mongolia) have officially abandoned socialism, and yet others (e.g., Fiji, Malaysia, Philippines) have always had capitalist societies. Because of such diversity, few policy formulations can be uniformly applied to the whole of the Asian region. It therefore becomes necessary to identify particular policies that are appropriate for particular subregions, countries, and even provinces or districts.

Yet the region also displays some overarching commonalities. For example, almost all societies confront issues concerning the role of the state in education. Likewise, almost all societies face issues related to expansion of access, and to supply of and demand for highly trained personnel. Also, all societies both benefit from and have to grapple with the advances in technology that may change curricula and modes of delivery in education; and all societies have to address tensions between well-established institutional structures and the new modes that may become necessary.

One striking feature of the last decade has been the advance of capitalist modes of operation in almost all parts of Asia. This has been especially obvious in the states that formally abandoned socialism, but has also been evident in those that officially maintain socialist regimes. Moreover, this development has been apparent even in countries that have long operated capitalist economies but that have had government-protected education systems. The chief manifestation of the change, as noted in previous issues of this publication, has been the advance of privatization in countries as different as Singapore and India. ${ }^{2}$

\section{Fees in Public Institutions}

The 1980s brought a worldwide trend toward the introduction of and increase in fees in public higher education. This was in direct opposition to the view dominant in the 1950s and 1960 s that public education, particularly at lower levels but also including higher education, should be free of charge. The chief justification was that education was a major route for social mobility, and the possibility of poor people being excluded from education by fees was considered inequitable.

By the 1990s, this notion had been widely abandoned. This was not only because of financial stringency but also because of the realization that fee-free education at the tertiary level, far from being equitable, was likely to be inequitable. Young people from richer socioeconomic groups are more likely than their counterparts from poorer socioeconomic groups to attend tertiary institutions, and subsidies for higher education are therefore more likely to benefit the rich than the poor.

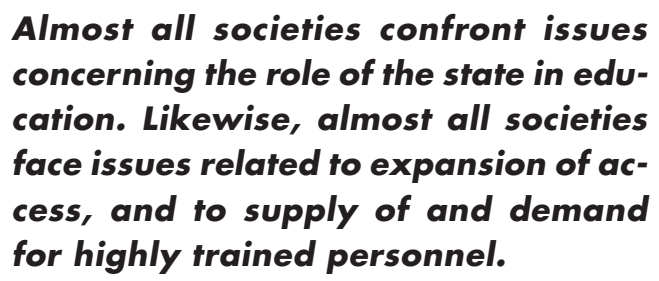

The Asian region has accompanied other parts of the world in the global shift in policy. According to a 1994 World Bank report, in the late 1980s in only 20 countries did tuition fees account for over 10 percent of recurrent expenditures. Sub-Saharan Africa, North Africa, the Middle East, and Eastern Europe had little or no tradition of cost recovery in public higher education. However, public-institution fees exceeded 10 percent of recurrent expenditures in one out of five Latin American countries and in half of the Asian countries.

As the 1990s progressed, in some parts of Asia fees increased further. In China, for example, the average 
fee in 1995 had reached 25 to 30 percent of recurrent costs. In Singapore, differential fees were charged by academic discipline. In the arts and social sciences, fees were increased from 10 percent of the recurrent cost in 1986-87 to 20 percent in 1992-93, and the government has declared its intent to raise fees further to 25 percent.

\section{Grants and Loans}

People who oppose such increases in fees usually do so on the grounds that fees are likely to exclude individuals from the poorest segments of society. Part of the response by policymakers has been to provide an array of support schemes, including grants and loans. Grants may be linked not only to incomes but also to academic performance and to efforts to attract students to particular types of training.

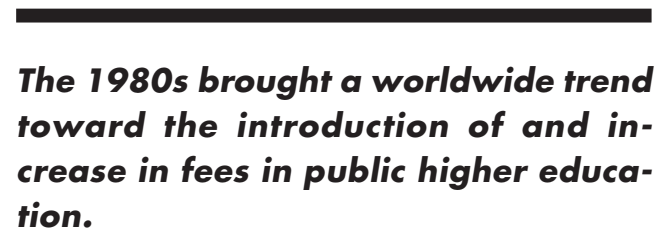

Loan schemes are much less efficient as a mechanism for cost recovery than is widely assumed. They usually contain a substantial proportion of hidden grants through subsidized interest rates, leniency for low-income students, and tolerance of default on repayment. In addition, loan schemes may demand substantial administrative costs.

Because of such factors, much attention during the 1990s has focused on ways to improve the efficiency of loan schemes. In Hong Kong, for example, the government was advised in 1996 to simplify administration and raise interest charges. When the scheme was initiated in 1969, loans were interest-free. However, in 1987 a 2.5 percent charge was introduced, and a 1996 report recommended that this should be raised to between 5.8 and 8.5 percent.

\section{Institutional Revenue-Earning Schemes}

Higher education institutions in Asia are increasingly required to secure additional funds from other sources. Many institutions now solicit donations from alumni; many encourage professors to undertake consultancy services; and some are moving into direct business ventures. Prosperous societies are obviously better able to support such initiatives than impoverished ones, though the irony is that institutions in prosperous societies have in general faced less need to secure independent revenues because their governments are better able to provide substantial funding. In the marketing of skills, institutions and individuals specializing in applied science and commerce generally have more opportunities than their counterparts specializing in history or philosophy.

Vietnam is among the countries in which higher education institutions have been forced, by escalating costs and the inadequacy of revenues from the government, to earn independent incomes. In 1991, Vietnam's College of Construction added 28.3 percent to its budget by taking on external contracts. Comparable figures were 22 percent for the Foreign Languages University, 11 percent for the College of Mining \& Geology, 10.5 percent for the Teachers Training College of Vinh, and 4.2 percent for the Technical Teachers College No. 1. Critics observe that such activities deflect the staff from their primary missions as specialized providers of higher education. Advocates usually agree, but point out that the activities at least permit the institutions to survive in harsh economic climates.

An example from a very different climate exists in Singapore. Although the country has a strong economy and has had continued government budget surpluses, even in Singapore the 1990s have brought a philosophy that higher education institutions should develop their own sources of revenue and reduce dependence on the government. In 1991, appeals were launched by Singapore's two universities for newly created endowment funds with a target of $\mathrm{S} \$ 1$ billion. The government contributed S\$500 million, and agreed to match up to $S \$ 250$ million during the following five years if the universities could secure that amount from nongovernment sources.

\section{Privatization}

Some observers view the privatization trend positively. For example, the World Bank has stated that:

Private institutions are an important element of some of the strongest higher education systems to be found today. ... They can respond efficiently and effectively to changing demand, and they increase educational opportunities with little or no educational cost. ${ }^{3}$

However, others have pointed out that the private sector includes opportunists and charlatans as well as reputable providers. In addition to local entrepreneurs, the opportunists include some ventures that have bases in North America, Europe, and Australasia but that market their wares in Asia. The 1990s have seen a rash of joint ventures and overseas operations in such countries as Malaysia and Japan, some of which are of very questionable quality and that offer degrees not accredited in their home countries. Laissez faire policies to- 
ward the private sector may also exacerbate problems in the labor market. In the Philippines, permissiveness produced an overproduction of graduates in some fields and underproduction in others.

These comments imply that some government oversight is needed in the sector. In most countries, public institutions will continue to educate the majority of students; but government planners can usefully promote coherence in the sector as a whole by facilitating flow of information on the costs and quality of different courses, and by establishing procedures for accrediting degrees from private institutions.

\section{Future Directions}

Returning to the theme with which this article began, patterns of financing for higher education in Asia display both commonality and diversity. The ADB works primarily with governments, and must operate within the framework of national contexts and policies. At the same time, the $\mathrm{ADB}$ and other international agencies can exercise leadership in facilitating change. The challenge is to tailor approaches to particular needs in specific situations and at particular points in time.

Many of the trends in Asia can also be found in other parts of the world. However, the Asian region does have some distinctive emphases. One, as noted, is in the scale of cost recovery through student fees. Another aspect is in the mix of institutions. The World Bank identifies Asia as "the continent where differentiation efforts have been the most extensive and most effective." ${ }^{4}$ This remark chiefly referred to the mix of conventional and distance-learning universities, and to the balance of public and private operations. Some systems are also differentiating between the nature and role of specific institutions. Institutions in the United States have long been divided into ones with a primary focus on teaching as opposed to others with a strong research function. A similar form of differentiation is being developed in China and India, for example.

The question is then what can be expected during at least the early years of the 21 st century. While prediction is always difficult and dangerous, several factors seem to be clear:

- Expansion. It seems probable that continued expansion will be a major feature. This will be particularly obvious in the socialist states that currently have low enrollment rates, including China, Laos, and Vietnam. Many capitalist states will also make renewed thrusts to reach higher enrollment rates. Economic downturn will threaten the scale of expansion, and in many contexts restructuring and improved efficiency will be needed.

- The Public-Private Mix. Countries such as South Korea and the Philippines already have such a high proportion of private higher education that it seems un- likely that the proportion will increase further. However, the private sector is likely to become increasingly evident in such countries as China, India, Kazakhstan, Uzbekistan, and Vietnam.

- Fees and loans. No sooner do populations become used to fees exceeding 10 percent of recurrent costs than authorities begin to talk of raising fees above 20 percent. It seems probable that present trends of cost sharing will continue. They will be supported by loan schemes of various kinds, and renewed attention will be given to the efficiency of those schemes.

\section{Loan schemes are much less efficient as a mechanism for costrecovery than is widely assumed.}

- Cost recovery through taxation. Countries with efficient taxation systems are likely to investigate in closer detail the possibility of using those systems for stronger cost recovery. This may be linked to student loans, as in Australia. Alternatively, governments may investigate schemes through which firms pay higher payroll taxes on graduates than on nongraduates.

- Distance Education. To some extent, the 1980s and 1990s have already brought a revolution through which conventional forms of higher education are supplemented with new forms of distance education, and these trends are likely to continue. The potential of the Internet in this domain is only beginning to become evident. At present, the Internet is dominated by the English language; but already it is being used for transmission in other languages, including those not based on alphabets, such as Chinese. Even libraries, conventionally conceived of as buildings full of books and journals, are likely to change. In the process, education will become more accessible to many (though not all) groups that are currently disadvantaged, and unit costs are likely to fall further.

\section{Notes}

1. Mark Bray, Financing Education in Developing Asia: Issues, Trends and Policy Implications (Manila: Asian Development Bank, 1998).

2. Philip G. Altbach, "Private Higher Education: Themes and Variations in Comparative Perspective," International Higher Education, no. 10 (1998): 1-6.

3. Higher Education: The Lessons of Experience (Washington D.C.: World Bank, 1994), 5.

4. Ibid., 30. 